\title{
KINERJA DINAS PERTANIAN DAN PETERNAKAN DALAM UPAYA PENINGKATAN PRODUKTIVITAS PETANI DI KABUPATEN ACEH BARAT
}

\author{
Najamuddin \\ Fakultas Ilmu Sosial dan Ilmu Politik Universitas Teuku Umar \\ najamuddin@utu.ac.id
}

\begin{abstract}
Performance apparaisal are one of important phase for an organization because the result reflect asan aacoomplish measurement reaching tree mission. This research used desrciptive method with qualitative. The research result shown that Performanceof Agricultur and Farm Departement of West Aceh Region has well run and need improvement as consist in the vision and mission that implemented on programs and event at each division in Agriculture and Fam Departemen of West Aceh Region. So as to improve Agriculture and Fam Departemen of West Aceh Region performance continously need cooperation well between manager and staf. A good cooperation between program cast and farmer parties became the objective program in order to improve farmer productivity toward society welfare.
\end{abstract}

Keywords:, Farmers, Performance, Productivity Improvement 


\section{PENDAHULUAN}

Pembukaan UUD 1945 menyebutkan tujuan nasional yang akan dicapai oleh Indonesia dan seluruh tumpah darah Indonesia, memajukan kesejahteraan umum, mencerdaskan kehidupan bangsa, dan ikut melaksanakan ketertiban dunia yang berdasarkan kemerdekaan, perdamaian abadi dan keadilan sosial. Amanat UUD 1945 tersebut menegaskan pentingnya upaya mewujudkan kesejahteraan rakyat dan kemajuan seluruh wilayah secara merata. Dalam upaya mencapai tujuan nasional tersebut, bangsa Indonesia menghadapi tiga arus utama perubahan yaitu Pertama, globalisasi yang di tandai oleh arus perpindahan barang dan jasa, modal, dan informasi secara bebas. Kebebasan itu menyebabkan batas antara pasar lokal, pasar daerah, pasar dalam negeri dan pasar internasional menjadi kabur. Kedua adalah pelaksanaan demokrasi dalam seluruh tatanan kehidupan bangsa. Ketiga, adalah penyelenggaraan otonomi daerah sebagai landasan pemerintahan, pembangunan dan pemberdayaan.

Kebijakan otonomi daerah yang dicanangkan oleh pemerintah dengan dikeluarkan Undang-Undang Nomor 23 Tahun 2014 tentang pemerintah daerah, memberikan, keleluasaan (disreationary power ) kepada daerah untuk mengurus dan mengatur rumah tangganya sendiri (Mahfud : 2000:5). Dalam situasi transisi dari monolik sentralistik kepada demokrasi lokal daerah dihadapan pada makin luasnya kewenangan mulai dari perencanaan hingga implementasi kebijakan guna melayani kepentingan masyarakat sesuai dengan potensi dan kondisi masingmasing daerah. The ultimate goal yang akan dicapai pada akhirnya adalah terciptanya kemandirian daerah dan kemandirian masyarakat berdasarkan asas demokrasi dan kedaulatan rakyat tanpa menganggu stabiltas nasional dan keutuhan wilayah NKRI. Sejalan dengan implementasi kebijakan desentralisasi tersebut setidaknya ada beberapa persoalan yang menjadi pekerjaan rumah yang diselesaikan oleh pemerintah daerah yaitu 1) Pengeloaan SDM Daerah, 2) Keuangan Daerah, 3) Peran dan Fungsi DPRD dan anggota DPRD, 4) Pengembangan organisasi pemerintah daerah, 5) Pelayanan masyarakat (Kantor Otda dan GTZUSAID:2000:12).

Sejalan dengan inplementasi kebijakan otonomi daerah, berbagai konflik kedaerahan terjadi belakangan ini antar daerah sebagai bentuk arogansi yang dilandasi oleh eksklusivisme merupakan pemahaman yang keliru tentang makna otonomi yang sesungguhnya. Hakekat meletakan otonomi daerah pada tingkat wilayah yang paling dekat dengan rakyat yaitu di kabupaten/kota memberikan makna untuk mendewasakan politik rakyat ( demokratization proces) dan meningkatkan kesejahteraan rakyat. Dalam proses administrasi maupun pengelolaan dan pemanfaatan potensi faktor ekternal dan internal organisasi yang sangat mempengaruhi terhadap peningkatan kinerja organisasi Dinas Pertanian dan Peternakan Kabupaten Aceh Barat adalah sosial, budaya, ekonomi, politik serta keamanan merupakan kekuatan, ancaman dan juga peluang terhadap peningkatan pengelolaan dan pemanfaatan potensi pertanian, peternakan dan perikanan.

Pemenuhan kebutuhan pangan sebagai salah satu peran strategis pertanian merupakan tugas yang tidak ringan, mengingat penduduk yang terbanyak di kabupten Aceh Barat adalah sebagai masyarakat tani. Kegiatan pertanian tanaman pangan dan holtikultura di Kabupaten Aceh Barat pada umumnya masih untuk kebutuhan sehari-hari. Jenis tanaman yang diusahakan oleh masyarakat kabupaten Aceh Barat adalah Padi, Jagung, Kedelai, Ubi Kayu, Ubi Jalar, Kacang Tanah dan Kacang Hijau, Dari data statistik Aceh Barat dalam angka tahun 2009 terlihat bahwa produksi padi, kacang tanah dan ubi kayu menunjukkan 42,368 ton 2.063,26 ton dan 1.585,95 ton menjadi jumlah produksi terbesar dari jenis produksi yang lain. Padi, Kacang tanah dan ubi kayu merupakan tanaman yang diusahakan oleh petani Kabupaten Aceh Barat. Hal ini berhubungan dengan makanan pokok penduduk asli daerah dan produksi palawija unggulan Kabupaten Aceh Barat. 
TABEL 1

PRODUKSI TANAMAN PADI DAN PALAWIJA TAHUN 2009

\begin{tabular}{|l|l|l|}
\hline No. & \multicolumn{1}{|c|}{ Jenis Produksi } & \multicolumn{1}{|c|}{ Jumlah (ton) } \\
\hline 1. & Padi & 42.368 \\
2. & Jagung & 654,48 \\
3. & Kedelai & 628,32 \\
4. & Ubi Jalar & 931,5 \\
5. & Kacang Tanah & 931,5 \\
6. & Kacang Hijau & $2.063,26$ \\
\hline & Jumlah & $46.645,56$ \\
\hline
\end{tabular}

Sumber : Dinas Pertanian dan Peternakan Kab. Aceh Barat

Tabel 2

Luas Lahan Sawah Yang Digarap Dan Yang Tidak Pada Tahun 2009 Dan 2010

\begin{tabular}{|c|c|c|c|}
\hline \multirow{2}{*}{ No } & \multirow{2}{*}{ Tahun } & \multicolumn{2}{|c|}{ Luas Lahan } \\
\cline { 3 - 4 } & & Yang digarap & Tidak digarap \\
\hline 1 & 2009 & $13.440 \mathrm{Ha}$ & $11.370 \mathrm{Ha}$ \\
\hline 2 & 2010 & $13.687 \mathrm{ha}$ & $11.123 \mathrm{ha}$ \\
\hline
\end{tabular}

Sumber : Dinas Pertanian dan Peternakan Kabupaten Aceh Barat

Tabel 3

Jumlah Produktivitas padi Sejak Tahun 2004 sampai dengan Tahun 2009

\begin{tabular}{|c|c|r|}
\hline No & Tahun & \multicolumn{1}{|c|}{ Produksi padi (ton) } \\
\hline 1 & 2004 & 114.807 \\
\hline 2 & 2005 & 58.458 \\
\hline 3 & 2006 & 25.253 \\
\hline 4 & 2007 & 71.370 \\
\hline 5 & 2008 & $44.199,28$ \\
\hline 7 & 2009 & 42.368 \\
\hline
\end{tabular}

Sumber : Dinas Pertanian dan Peternakan Kabupaten Aceh Barat.

Hasil ini mengambarkan produksinya masih sangat sedikit jika dibandingkan dengan luas lahan yang tersedia dan kemauan untuk mengembangkan budi daya padi dan palawija. Pada saat ini sesuai data pada tahun 2010 jumlah penyuluh pertanian sebanyak 86 orang merupakan sumber daya yang sangat potensial untuk mendorong lajunya produktivitas padi yang ada pada kelompok tani yang tersebar dalam Kabupaten Aceh Barat. Oleh karena itu diperlukan penanganan yang terencana secara terpadu sehingga dapat menguasai pasar lokal, regional dan nasional.

Strategi peningkatan kinerja aparatur Dinas Pertanian dan Peternakan Kabupaten Aceh Barat pada hakekatnya adalah upaya terencana untuk meningkatkan kapasitas pemerintahan daerah Kabupaten Aceh Barat yang andal dan profesional yang pertama adalah penentuan atau pemetaan potensi, pertanian, peternakan, perkebunan dan perikanan menentukan tempat yang strategis dimana dijadikan sebagai pusat produksi ternak, pusat pembenihan tanaman pangan dan holtikultura dan bibit unggul dan agrobisnis. Memperbaiki dan meningkatkan kwalitas sumber daya manusia pertanian dan mempersiapkan sarana dan prasarana sebagai sumber daya daerah secara berdaya guna dan berhasil guna bagi kemajuan daerah dan kesejahteraan masyarakat. Ada dikotomi pemerintahan dua urusan yaitu: urusan pilihan dan urusan wajib. Urusan wajib adalah pelayanan dasar sedang urusan pilihan adalah pengembangan sektor 
keunggulan daerah yang pelaksana otonomi dan pelaksana teknis salah satu diantaranya adakah satuan kerja perangkat daerah ( SKPD ) Dinas Pertanian dan Peternakan Kabupaten Aceh Barat. Tugas dan fungsinya adalah pelaksana otonomi daerah dan tugas melaksanakan urusan pemerintahan daerah berdasarkan asas otonomi dan tugas pembantuan.

Penataan kelembagaan melaksanakan prinsip mendapatkan orang yang tepat pada tempat yang tepat (The Right Man On The Right Place) dan menerapkan prinsip mampu memahami dan mewujudkan pemerintahan yang baik ( Good Governance) secara strategis dan mewujudkan dan pencapaian peningkatan kinerja pemerintahan daerah yang efektif dan efisien. Disamping itu, pembangunan pertanian di daerah merupakan upaya untuk memberdayakan masyarakat mempunyai pilihan yang luas untuk mengembangkan kehidupan yang lebih maju, mandiri, makmur, sejahtera dan bermartabat. Peningkatan kinerja aparatur dinas pertanian dan peternakan Kabupaten Aceh Barat yang dilaksanakan oleh seluruh masyarakat, Seluruh Anggota kelompok tani, ternak serta seluruh stakeholder berlandaskan asas keseimbangan dan kerja sama kemitraan antara pemerintah, dunia usaha, komunikasi dan interaksi lintas pelaku secara terbuka dan demokrastis, manajemen Dinas Pertanian dan Peternakan Kabupaten Aceh Barat yang efisien dan efektif serta tata guna lahan, pembenihan dan pembibitan, pembiayaan petani, kelembagaan petani pengelolaan dan pemanfaatan sumber daya alam dan lingkungan hidup yang memenuhi kaidah pembangunan pertanian yang berkelanjutan.

Kabupaten Aceh Barat mempunyai potensi sumber daya alam yang paling besar di sektor perikanan perkebunan, peternakan, holtikultura, pertambangan dan tanaman pangan dan juga memiliki tingkat kerawanan untuk pelarian sumber daya dari Kabupaten Aceh Barat dengan letak Geografis paling strategis, wilayah yang sangat luas dan pemanfaatkan yang masih rendah juga membutuhkan jaringan infrastruktur yang saat ini masih sangat memprihatinkan. Kondisi sebagian sarana dan prasarana dalam wilayah Kabupaten Aceh Barat yang mempuruk situasi kapabilitas aparatur dan kondisi masyarakat antar Kecamatan akibat kurangnya sarna trasnportasi yang memadai. Tantangan terbesar adalah meberikan pelayanan masyarakat wilayah yang letaknya terpencil dari Ibu Kota Kabupaten Aceh Barat. Adapun permasalahan yang terjadi yaitu sebagai berikut :

1. Banyaknya lahan pertanian yang kosong yang semestinya dapat diolah untuk menghasilkan padi dibiarkan terlantar, sehingga diperlukan dorongan kepada petani agar termotivasi untuk menggarap tanah kosong tersebut.

2. Kurangnya sosialisasi terkait pengembangan produktivitas padi oleh Dinas Pertanian dan Peternakan Kabupaten Aceh Barat kepada Kelompok Tani.

3. Tingginya tergantungan masyarakat Kabupaten Aceh Barat terhadap kebutuhan Beras yang di datangkan dari luar daerah.

4. Hasil produksi padi yang cenderung turun di Kabupaten Aceh Barat.

Berdasarkan latar belakang dan permasalahan diatas, tulisan ini mencoba untuk menganalisis Bagaimanakah kinerja Dinas Pertanian dan Peternakan dalam upaya peningkatan produktivitas Petani sehingga tidak selalu tergantung produktivitas padi dari daerah luar?

\section{TINJAUAN LITERATUR}

\section{Sistem Akuntabilitas Kinerja Instansi Pemerintah (SAKIP).}

Sistem Akuntabilitas Kinerja Instansi Pemerintah (SAKIP), adalah rangkaian sistematik dari berbagai aktivitas, alat dan prosedur yang dirancang untuk tujuan penetapan dan pengukuran, pengumpulan data, pengklasifikasian, pengikhtisaran dan pelaporan kinerja pada instansi pemerintah, dalam rangka pertanggung jawaban dan peningkatan kinerja instansi pemerintah. 


\section{Perencanaan Strategis(Renstra)}

Perencanaan Strategis merupakan suatu proses yang berorientasi pada hasil yang ingin dicapai selama kurun waktu satu sampai dengan lima tahun secara sistematis dan berkesinambungan dengan memperhitungkan potensi, dan kendala yang ada atau yang mungkin timbul. Proses ini menghasilkan suatu rencana strategis instansi pemerintah, yang setidaknya memuat visi, misi, tujuan, sasaran, strategi, kebijakan dan program serta ukuran keberhasilan dan kegagalan dalam pelaksanaannya. Instansi pemerintah harus termotivasi dari waktu kewaktu, berusaha berubah kearah yang baik. Perubahan tersebut harus disusun dalam suatu tahapan yang konsisten dan berkelanjutan, yang mengarah pada peningkatan akuntabilitas dan kinerja yang berorientasi kepada pencapaian hasil.

\section{Indikator kinerja.}

Indikator kinerja (out put) adalah segala sesuatu berupa produk/jasa sebagai hasil langsung dari pelaksanaan suatu kegiatan dan program berdasarkan masukan yang digunakan. Sedangkan indikator kinerja hasil (out come) adalah segala sesuatu yang mencerminkan berfungsinya keluaran kegiatan pada jangka menengah. Indikator kinerja disajikan dalam penyusunan sasaran sebaiknya diutamakan indikator kinerja outcome.

\section{Pengukuran Kinerja.}

Pengukuran kinerja adalah proses penilaian yang sistematis dan berkesinambungan untuk menilai keberhasilan atau kegagalan pelaksanaan kegiatan sesuai dengan program, kebijakan dan sasaran dan tujuan yang telah ditetapkan dalam mewujudkan visi, misi dan stratejik instansi pemerintah. Proses ini dimaksudkan untuk menilai pencapaian setiap indikator kinerja guna memberikan gambaran tentang keberhasilan dan kegagalan pencapaian tujuan dan sasaran. Selanjutnya dilakukan pula analisis akuntabilitas kinerja yang menggambarkan keterkaitan pencapaian kinerja kegiatan dengan program dan kebijakan dalam rangka mewujudkan sasaran, tujuan, visi, misi sebagaimana ditetapkan dalam renstra. Pengukuran kinerja kinerja merupakan subsistem kedua dari sistem Akuntabilitas Kinerja Instansi Pemerintah ( AKIP ). Setelah subsistem perencanaan kinerja dan kemudian dilanjutkan dengan subsistem pelaporan kinerja. Selanjutnya, hasil pengukuran kinerja yang dilengkapi dengan analisis dan evaluasi atas capaian kinerja disajikan dan pelaporan kinerja.

Kinerja organisasi pemerintah daerah banyak di pengaruhi oleh faktor lingkungan internal maupun lingkungan eksternal organisasi pemerintahan setelah adanya perubahan undangundang tentang pemerintahan daerah. Menurut Atmosoeprapto (2000:11-19 ) mengemukakan kinerja suatu organisasi akan sangat dipengaruhi oleh faktor internal maupun faktor ekternal maupun faktor eksternal seperti berikut ini :

a. Faktor internal yang terdiri dari :

1. Tujuan, yaitu apa yang ingin dicapai dan apa yang ingin diproduksi oleh suatu organisasi.

2. Struktur organisasi ( kelembagaan), yaitu sebagai hasil desain antara fungsi yang akan dihasilkan oleh unit organisasi dengan struktur formal yang ada.

3. Sumber Daya Manusia ( Kompetensi aparatur ), yaitu kualitas dan pengelolaan anggota organisasi sebagai penggerak jalannya organisasi keseluruhan.

4. Budaya organisasi, yaitu gaya dan identitas suatu organisasi dalam pola kerja baku dan menjadi citra organisasi yang bersangkutan.

b. Faktor eksternal yang terdiri dari :

1. Faktor sosial, yaitu orientasi nilai yang berkembang ditengah masyarakat yang mempengaruhi pandangan mereka terhadap etos kerja yang dibutuhkan bagi peningktan kinerja organisasi. 
2. Faktor ekonomi, tingkat perkembangan ekonomi yang berpengaruh pada tingkat pendapatan masyarakat sebagai daya beli untuk menggerakkan sektor-sektor lainnya sebagai suatu sistem ekonomi yang lebih besar.

3. Faktor politik, yaitu hal yang berhubungan dengan keseimbangan kekuasaan negara yang berpengaruh pada keamanan dan ketertiban yang akan mempengaruhi ketenangan organisasi untuk bekarya secara maksimal.

Kedua faktor diatas sangat mendominasi jalannya sistem pemerintahan di daerah, sehingga dapat dikemukakan bahwa faktor lingkungan internal ini pada umumnya terjadi dalam lingkungan organisasi itu sendiri. Menurut David dan Thomas (2003:11-12) faktor lingkungan internal terdiri dari Variabel-variabel ( kekuatan dan kelemahan ) yang ada di dalam organisasi tetapi biasanya tidak dalam pengendalian jangka pendek dari manajemen puncak. Variabelvariabel tersebut membentuk suasana di mana pekerjaan dilakukan. Variabel-variabel itu meliputi struktur, budaya dan sumber daya organisasi. 


\section{Kerangka Pemikiran}

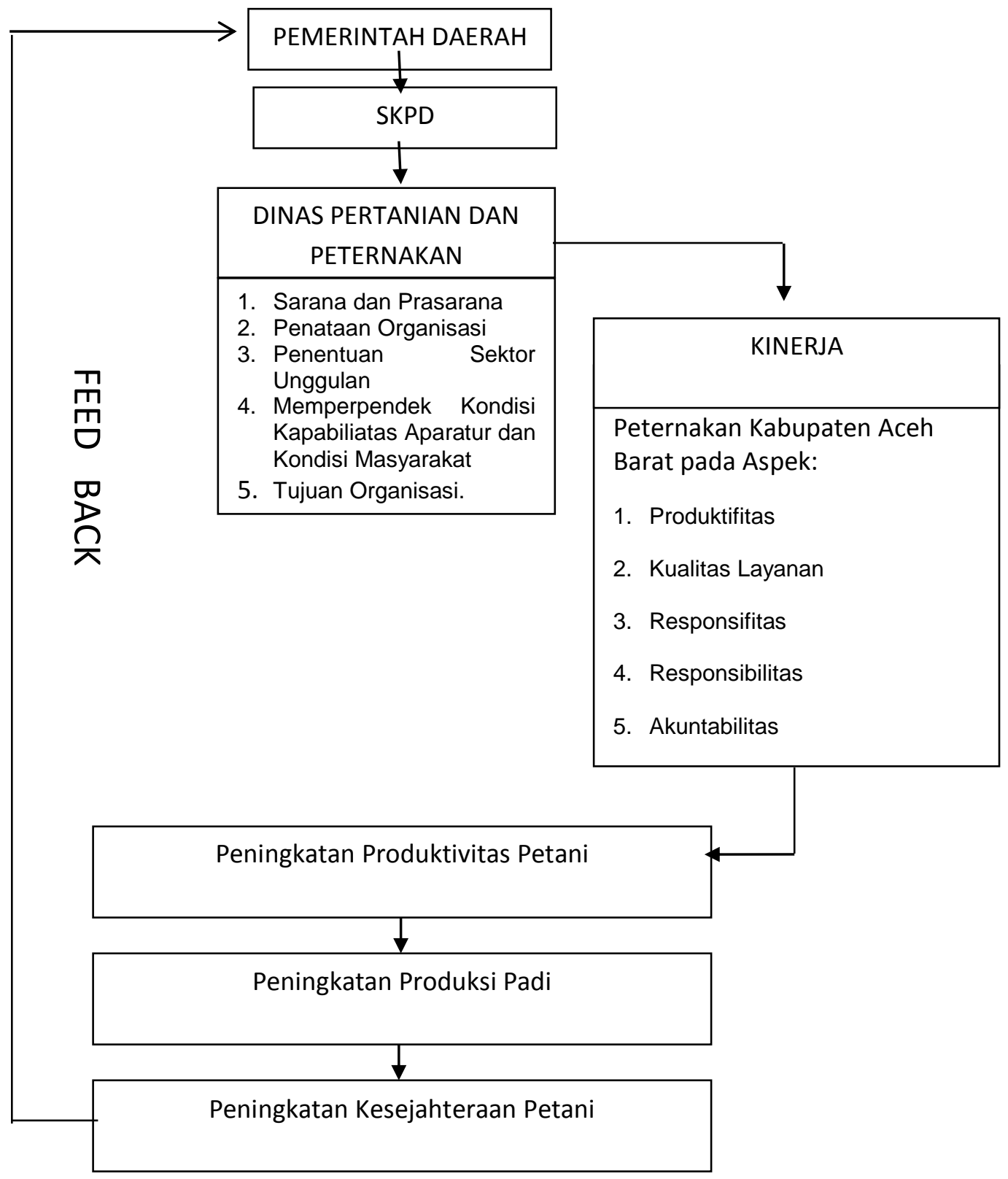

GAMBAR:

Kerangka Pemikiran

\section{METODE PENELITIAN}

Metode penelitian yang digunakan dalam penelitian ini yaitu metode penelitian deskriptif dengan pendekatan kualitatif. Adapun yang menjadi lokasi penelitian ini adalah Gampong Gunong Mulinteung Kecamatan Panga Kabupaten Aceh Barat, Provinsi Aceh. Teknik pengumpulan data dilakukan melalui kepustakaan dan lapangan. Kepustakaan dengan membaca buku teks dan bahan bacaan lainnya yang berkaitan dengan tema penelitian untuk menganalisis dengan menggunakan teori yang digunakan. Sedangkan lapangan dengan mewawancarai para informan yang menjadi sumber informasi bagi penulis untuk mendapatkan data secara akurat. 
Sedangkan teknik analisis data yaitu Proses analisis data dimulai dengan menelaah seluruh data yang tersedia dari berbagai sumber, setelah menelaah langkah berikutnya yaitu mereduksi data dengan melakukan abstraksi atau membuat rangkuman inti. Tahap ketiga yaitu menyusun datadata tersebut dalam satuan-satuan dan tahap akhir dari analisis data ialah melakukan pemeriksaan keabsahan data (Moleong, 2002: 247).

\section{HASIL PENELITIAN DAN PEMBAHASAN}

Kinerja dinas pertanian dan peternakan dalam meningkatkan produktivitas petani padi di kabupaten Aceh Barat dapat di lihat dari beberapa indikator yang telah ditentukan yang biasanya digunakan untuk mengukur kinerja birokrasi publik diantaranya adalah sebagai berikut:

\section{Produktivitas}

Produktivitas tidak hanya untuk mengukur tingkat efosiensi, akan tetapi juga dipakai untuk mengukur efektivitas pelayanan. Produktivitas pada umumnya dipahami sebagai rasio antara input dan output. Dari data yang didapatkan dilapangan mengungkapkan bahwa akuntabilitas kinerja Dinas Pertanian Dan Peternakan Kabupaten Aceh Barat tahun 2011 dari total Pagu dana APBK dan APBN sebesar Rp. 20.097.862.646,- telah dapat dibelanjakan sebesar Rp.20.028.614.646 dengan sisa anggaran sebesar 69.248.000,- yang berarti dapat disimpulkan bahwa rata-rata capaian kinerja dalam hal perbandingan input dan output $99,66 \%$. Dalam bidang pertanian mencapai $68 \%$ yang berarti telah mencapai kinerja yang baik.

\section{Kualitas Layanan}

Kinerja Dinas Pertanian Dan Peternakan Kabupaten Aceh Barat yang berkaitan dengan kualitas layanan cendrung menjadi penting dalam menjelaskan kenerja organisasi pelayanan publik, dengan demikian kepuasan masyarakat terhadap layanan dapat dijadikan indikator kenerja organisasi publik, informasi mengenai kepuasan terhadap kualitas pelayanan seringkali dapat diperoleh dari media masa atau diskusi publik, dari data yang penulis temukan bahwa berdasarkan wawancara dan laporan Akuntabilitas Kenerja Dinas Pertanian dab Perternakan Tahun 2011, bahwa kenerja Dinas Pertanian dan Perternakan dalam peningkatan Kuwalitas pelayanan terhadap peningkatan produktivitas petani sudah terlaksana dengan baik,

\section{Responsifitas}

Kenerja Dinas Pertanian dan Perternakan Kabupaten Aceh Barat dalam peningkatan produksivitas petani padi, responsifitas adalah kemampuan birokrasi untuk mengali kebutuhan masyraka, menyususn agenda dari pioritas pelayanan dan mengembangkan pogram-pogrampelayanan publik sesuai dengan aspirasi masyarakat"

Dari data yang penulis temukan berdasarkan wawancara dan laoran Akuntabilaitas Kenerja Dinas Pertanian dan Perternakan than 2011, bahwa kenerja berkaitan responitifitas Dinaas Pertanian dan perternakan dalam peningkatan Produktivitas petani padi telah terlaksana dengan baik

\section{Resposibilitas}

Kenrja Dinas Pertanian dan perternakan Kabupaten Aceh Barat reponsibilitas yaitu menjelaskan apakah pelaksanaan kegiatan birokrasi publik itu dilakukan sesuai dengan prinsip-prinsip adminitrasi yang benardengan kebijakan birokrasi, baik yang ekplisit maupun inplisit, 
Dari data yang penulis temukan dengan wawacara dan laporan Akuntabilaitas Kenerja Dians Pertanian dan Perternkan tahun 2011, bahwa kenerja Dinas pertanian dan Perternakan berkaitan Responsibilitas peningkatan produktivitas petani padi telah terlaksana dengan baik

\section{Akutabilitas}

Kenerja Dinas Pertanian dan Perternakan Kabupaten Aceh Barat dalam peningkatan produktivitas petani padi, akuntabilitas adalah kinerja akuntabilitas menujuk seberapa besar kebijakan dalam kegiatan birokrasi publk tunduk pada Para pejabat politik yang terpilih oleh rakyak. Asumsinya adalah bahwa Para pejabat politik karena dipilih oleh rakyat, dengan sendirinya akan selalu memprentasikan kepentingan rakyat,

Dari data yang penulis temukan dengan wawancara dan laporan Akuntabilitas Kinerja Dinas Pertanian dan Perternakan tahun 2011, bahwa Kinerja Dinas Pertanian dan Perternakan yang berkaitan Akutabilitas telah terlaksana dengan baik

\section{SIMPULAN DAN SARAN}

\section{A. Simpulan}

Berdasarkan pembahasan dan analisis data diatas menunjukkan bahwa Kinerja aparatur pada Dinas Pertanian dan Peternakan Kabupaten Aceh Barat yang dilihat dari aspek efektivitas yaitu pemahaman terhadap tugas yang dberikan kepada pegawai, tingkat kualitas pelayanan aparat yang diberikan terhadap masyarakat pengguna jasa serta relevansi program-program kegiatan yang dilaksanakan dalam organisasi dapat disimpulkan baik. Kinerja aparatur pada Dinas Pertanian dan Peternakan Kabupaten Aceh Barat sangat dipengaruhi oleh faktor budaya dan kepemimpinan yang ditunjukkan para pemimpin kepada pegawai melalui sikap dan keteladanan serta etos kerja yang tinggi dapat mempengaruhi perilaku aparat serta memberikan motivasi dalam rangka memberikan pelayanan kepada masyarakat pengguna jasa untuk mencapai visi misi Dinas Pertanian dan Peternakan Kabupaten Aceh Barat.

\section{B. Saran}

1. Mempersiapkan para pegawai dengan cara mengikutkan pada kursus-kursus atau pelatihan teknis untuk meningkatkan kemampuan dan pengetahuan yang lebih mendalam di bidang tugasnya serta menerapkan mekanisme kontrol yang tepat.

2. Mengevaluasi keluhan-keluhan serta saran dari masyarakat/pengguna jasa dan mencari titik lemahnya sehingga produk pelayanan yang dihasilkan gagal, serta mencari solusi untuk memperbaiki pelayanan.

3. Meningkatkan pengaruh positif kepada pegawai di lingkungan Dinas Pertanian dan Peternakan Kabupaten Aceh Barat dengan cara memberikan contoh-contoh atau teladan yang baik, mempunyai kewibawaan di depan pegawai agar dapat menumbuhkan rasa segan ataupun rasa hormat, mempunyai skill yang lebih baik dari pegawai sehingga apabila dalam suatu pekerjaan tidak dapat dilaksanakan oleh pegawai, dengan cepat dapat diselesaikan oleh pemimpin tugas/pekerjaan yang sulit dilakukan oleh pegwai.

4. Meningkatkan peranan informasi, memonitor secara langsung setiap pelaksanaan tugastugas yang diberikan serta dapat memberikan petunjuk/saran kepada pegawai dalam pelaksanaan tugas.

5. Menerapkan sistem yang lebih partsipatif dengan lebih memberi kesempatan kepada pegawai untuk dapat menyampaikan aspirasi yang berkaitan dengan tugas dan pekerjaannya agar lebih tecipta suasana yang kondusif dalam pelaksanaan tugas di kantor.

6. Lebih menumbuhkan kesadaran pegawai untuk meningkatkan etos kerja yang tinggi dalam pelaksanaan tugas, sehingga pegawai lebih menyadari hakekat tugas dan kewajibannya di kantor. 


\section{DAFTAR PUSTAKA}

Andi Prastowo, ( 2009), Menguasai Teknik- teknik koleksi Data Penelitian Kualitatif, Diva Pres ( Anggota IKAPI), Yogyakarta.

Budi Nevizond Chatab, (2007), Profil Budaya Organisasi, Alfabeta, Bandung .

Dwiyanto, Agus dkk, 2002, Reformasi Birokrasi di Indonesia, Pusat Studi Kependudukan dan Kebijakan, Universitas Gajah Mada, Yogyakarta.

Edi Suharto, ( 2005) Membangun Masyarakat Memberdayakan Rakyat, PT. Refika Aditama, Bandung.

Elfindri, (2008), Strategis Sukses Membangun Daerah, Gorga Media, Jakarta.

Faisal Basri, (2005). Perencanaan Strategis, Media Grafika, Jakarta.

Fredy Rangkuti (1997). Analisis SWOT Teknik Membedah Kasus Bisnis, Reorientasi Konsep Renana Strategis Untuk menghadapi Abad 21, Jakarta : Gramedia Pustaka Utama.

Gary Yukl,(2007), Kepemimpinan Dalam Organisasi, PT. Indeks. Jakarta .

Hetifah Sj. Sumarto, (2009), Inovasi, Partisipasi dan Good Governance, Yayasan Obor Indonesia, Jakarta.

Harbani Palosong, (2007), Teori Adminstrasi Publik, Alfabeta Bandung.

Inuh Kencana Syafiie, (2007), Manajemen Pemerintahan, PT. Perca, Jakarta.

Khasan Efendi, (2009), Pengembangan Organisasi, CV. Indra Pustaka, Bandung .

Keban Yarenas T. 1995, Indikator Kinerja Pemerintah Daerah, Pendekatan Manajemen dan Kebijakan, Yogyakarta: Fisipol UGM.

Khasan Effendi, 2009, Otonomi Desa, CV. Indra Prahasta, Bandung.

Lexy J. Moleong, (2010) Manajemen Keuangan Daerah. Model Kuliah Program Pasca Sarjana Magister Administrasi Pemerintahan Daerah, IPDN Jakarta.

Marsono, (2005), Kepala Daerah Pilihan Rakyat, CV. Eko Jaya, Jakarta.

Matthew B. Miles A. Michael Huberman,(1992), Analisis Data Kualitatif, Universitas Indonesia, Jakarta.

Muhammad Jusuf Kalla, (2009) Membangun Bangsa Dengan Kemandirian Ekonomi, Focus Gramedia, Jakarta Timur.

Narbuko, Cholis dan Achmadi, H. Abu, (2001). Metodologi Penelitian, Bumi Aksara, Jakarta.

Rosida. Ambar Teguh Sulistiyani, (2005), Menjadi Sekretris Profesional dan Kantor yang eksekutif, Gaya Media, Yogyakarta. 
Rusidi,(2002), Pedoman Penelitian dan Penulisan Karya Ilmiah, Bandung : UPT Penerbitkan IKOPIN.

Rustian Kamaluddin, (1993), Beberapa Aspek Pembangunan Nasional dan Daerah, Ghalia Indonesia, Jakarta Timur.

Sanerya Hendrawan, (2009), Spritual Management, PT. Mizan Pustaka. Ujung Berung, Bandung.

Sedarmayanti, (2009), Reformasi Administrasi Publik, Reformasi Birokrasi dan Kepemimpinan.

Sedarmayanti, (2007), Manajemen Sumber Daya Manusia, PT. Reflika Aditama, Bandung.

S. Prajudi Admosudirjo, (1994) Hukum Administrasi Negara, Ghalia Indonesia, Jakarta.

Sugiono, (2009), Metode Penelitian Administrasi , CV. Alfabeta, Bandung.

Salusu, (1998), Pengambilan Keputusan Strategik; Untuk Organisasi Kinerja dan Oranisasi Non Profit, Jakarta : Gramedia.

Siagian, Sondang, P, (2007) Manajemen Strategik, Jakarta: Bumi Aksara.

Sadu Wasistiono, (2006) Memahami asas Tugas Pembantuan, Fokusmedia, Panghegar Bandung.

Sudarto, (2002), Metodelogi Penelitian Filsafat, PT. Raja Grafindo Persada, Jakarta.

Sadu Wasistiono, (2006), Prospek Pengembangan Desa, Fokusmedia, Bandung.

Sadu Wasistiono, (2003), Kapita Selekta Manajemen Pemerintahan Daerah, CV. Fokus Media, Bandung.

Sri Wahyudi, Agustus 1996, Manajemen Strategik, Pengantar Proses Berfikir Strategis, Jakarta : Binarung Aksara.

Sadu Wasistiono, (2009), Perkembangan Organisasi Kecamatan Dari Masa Ke Masa, Fokusmedia, Bandung.

Sugiyono, (2008), Metode Penelitian Pendidikan Kualitatif dan Kuantatif, dan Kuantitatif, Alfabeta Bandung.

Sondang P. Siagian, (2003) Filsafat Administrasi, PT. Bumi Aksara, Jakarta.

Suhendra,(2006), Peranan Birokrasi Dalam Pemberdayaan Masayarakakt, Alfabeta, Bandung.

Tjahya Supriatna, (2000), Strategi Pembangunan dan Kemiskinan, PT. Rineka Cipta, Jakarta.

Sadu Wasistiono, , (2002), Menata Ulang Kelembagaan Pemerintahan Kecamatan, Cipta Pindo Anggota IKAPI, Bandung.

Widodo, (2004) Membangun Birokrasi Berbasis Kinerja, Bayumedia, Malang. 


\section{Peraturan Perundang-undangan}

Pembukaan UUD Negara Republik Indonesia dan Pasal 18 UUD 1945 Tentang Pemerintah.

UU Nomor 32 dan 33 tentang Pemerintahan Daerah dan Perimbangan Keuangan pusat dan daerah.

UU Nomor 21 Tahun 2001 Tentang Otonomi Khusus, RPJP, RPJM, Badang Perencanaan Pembangunan Nasional Tentang Pengembangan Wilayah. 